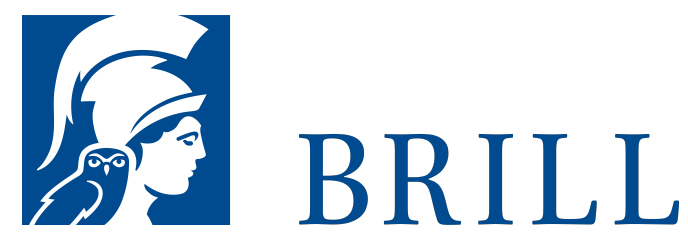

\title{
Alojzije Stepinac
}

Die Biografie

Author: Claudia Stahl

Alojzije Stepinac war als Erzbischof von Zagreb ein Gegner von Nationalsozialismus und Kommunismus. Noch immer wirkt seine ideologisch geprägte Verurteilung nach. Heute steht er vor der Heiligsprechung. Stepinac unterstützte besonders im Zweiten Weltkrieg Notleidende und Verfolgte in großer Zahl und ohne Unterschiede. Öffentlich trat er für die Menschenrechte ein. Tito ließ ihn 1946 in einem international beachteten Schauprozess verurteilen. Den Rest seines Lebens verbrachte er in Gefangenschaft. Dennoch wirkte er weiter durch Briefe und Predigten und wurde Kardinal. Die Ursache seines Todes 1960 ist nicht völlig geklärt. Nach seiner Seligsprechung 1998 läuft nun das Heiligsprechungsverfahren. Die erste vollständige Biografie in deutscher Sprache bezieht bisher unbekannte Dokumente mit ein und beleuchtet die historischen Bedingungen seines Wirkens und sein Verhältnis zu Deutschland.

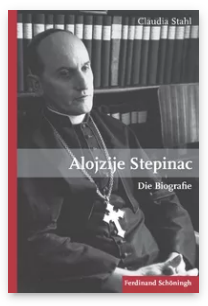

Pages: 592

Seiten, $24 \mathrm{~s} / \mathrm{w}$

Abb.

Language:

German

Subjects:

Contemporary

History, History

Publisher: Brill |

Schöningh

E-Book (PDF)

Released online: o1 Sep 2017

ISBN: $978-3^{-}$

657-78773-9

List price

Hardback

Publication date:

14Jul 2017

ISBN: 978-3-

506-78773-6

List price 
Claudia Stahl absolvierte ein Studium der Rechtswissenschaft, Musikwissenschaft und Philosophie. Heute arbeitet sie als Richterin im Land Brandenburg.

For more information see brill.com

Order information: Order online at brill.com +44 330 333 0049 | customerservices@brill.com Submission information: brill.com/authors

Titles published by Brill | Fink, Brill | mentis or Brill | Schöningh: +49(o)71 5413279216 | brill@brocom.de 